\title{
The carotid intima media thickness in coal miners
}

\section{Kömür madeni işçilerinde karotis intima mediya kalınlığı}

\author{
Emine ALTUNTAŞ®, Emine GENCERఠ, Hümeyra ÇiçEKLER $\odot$, Emek Tolga IŞILDAK
}

\begin{abstract}
Aim: The cardiovascular diseases are one of the most frequent causes of death in coal miners. Atherosclerosis is the most frequent cause of cardiovascular disease around the world. The subclinical atherosclerosis can be diagnosed thanks to the localization of carotid arteries by measuring carotid intima media thickness via Doppler ultrasonography. In this study, the aim was to investigate whether the chronic exposure to coal mine dust contributes to atherosclerotic process.
\end{abstract}

Method: The study was designed as a single center, retrospective survey, consisting of 25 young coal miners, 25 veteran coal miners, 25 young people and 25 healthy elderly people who have never exposed to coal mine dusts. The carotid Doppler ultrasonography, biochemical tests, echocardiography, respiratory function test results were recorded from the files of the cases.

Results: There was not any significant difference as for carotid intima- media thickness between coal miners and healthy young group $(0.66 \pm 0.16$ vs $0.65 \pm 0.16 ; p=0.994)$, while there was a significant difference between veteran coal miners and healthy elderly group (0.99 \pm 0.09 vs. $0.81 \pm 0.13 ; p<0.05)$.

Conclusion: In this study, it was found that the carotid intimamedia thickness, which is used in order to diagnose atherosclerosis in early stage, increased after chronic exposure to coal mine dust. Therefore, it can be thought that professional questioning may be beneficial while determining the risk factors of individuals in terms of atherosclerosis.

Keywords: Occupational exposure, carotid intima-media thickness, atherosclerosis
Öz

\begin{abstract}
Amaç: Kömür madeni işçilerinde ölümün en sık nedenlerinden biri kardiyovasküler hastalıklardır. Ateroskleroz dünya çapında kardiyovasküler hastalıkların en sık nedenidir. Subklinik ateroskleroz karotis arterlerin yerleşimi sayesinde Doppler ultrasonografi aracılığıyla teşhis edilebilir. Bu çalışmada, amaç kömür madeni tozuna kronik maruziyetin aterosklerotik sürece katkısı olup olmadığını araştırmaktı.
\end{abstract}

Yöntem: Çalışma tek merkezli ve retrospektif olup, 25 genç kömür madeni iş̧̧isi, 25 kömür madeni emeklisi, 25 genç ve 25 yaşlı sağlıklı ve kömür tozu maruziyeti olmayan kontrollerden oluşmaktaydı. Olguların dosyalarından karotis Doppler ultrasonografisi, biyokimyasal testleri, ekokardiyografisi, solunum fonksiyon testi bulundu ve kaydedildi.

Bulgular: Genç maden işçisi grubu ile sağlıklı genç kontroller arasında karotis intima mediya kalınlığı arasında anlamlı fark bulunmazken $(0,66 \pm 0,16$ vs $0,65 \pm 0,16 ; p=0,994)$, kömür madeni emeklisi grup ile sağlıklı ve yaşlı kontroller arasında anlamlı fark oluştuğu görüldü $(0,99 \pm 0,09$ vs. $0,81 \pm 0,13 ; p<0,05)$.

Sonuç: Bu çalışmada, aterosklerozun erken dönemde teşhisini sağlayan karotis intima mediya kalınlığının kronik kömür tozu maruziyeti sonrası arttığı görüldü. Bu nedenle kişilerin ateroskleroz açısından risk faktörlerini belirlerken mesleki sorgulamının yararlı olabileceği düşünülebilir.

Anahtar kelimler: Mesleki maruziyet, karotis intima mediya kalınlığı, ateroskleroz

\footnotetext{
Received: 07.05.2018

Accepted: 29.09.2018

${ }^{1}$ Zonguldak Atatürk State Hospital, Department of Cardiology, Zonguldak, Turkey

2Zonguldak State Hospital, Department of Pulmonology, Zonguldak, Turkey

${ }^{3}$ Zonguldak Atatürk State Hospital, Department of Biochemistry, Zonguldak, Turkey

${ }^{4}$ Zonguldak Atatürk State Hospital, Department of Radiology, Zonguldak, Turkey

Corresponding author: Emine Altuntaş, Zonguldak Atatürk State Hospital, Department of Cardiology, Zonguldak, Turkey e-mail: emine_altuntas@hotmail.com
}

ORCID ID's:

E.A. 0000-0001-5887-5422, E.G. 0000-0002-5718-626X, H.Ç. 0000-0003-4132-0708 


\section{INTRODUCTION}

The endothelium is a vascular layer which has highly important tasks in order to circulate blood normally in vascular system. The endotelial dysfunction causes many diseases which are associated with cardiovascular system by triggering atherosclerotic process. Atherosclerosis related diseases are the most important causes of mortality and morbidity around the world. Atherosclerosis induces the development of systemic disease by affecting large and medium arteries, and when the clinical manifestations of the disease occur, the disease is usually advanced. Subsequent interventions are usually directed to secondary prevention or palliation ${ }^{1}$. Diagnosis of atherosclerotic changes in subclinical period may be important so as to reduce risk factors. The intima- media thickness increases during subclinical period ${ }^{2-4}$. Because the carotid arteries are not deeply located, imaging is easy. The measure of intima media thickness with ultrasonographic method is noninvasive, repeatable, easy and costeffective. The ultrasonography allows the detection of asymptomatic individuals by measuring carotid intima-media thickness (CIMT).

The need for energy has increased with the beginning of industrialization in the world and thus various natural resources, especially coal, are used. Coal miners work in limited space, so they are exposed to high temperature, humidity, noise, vibration and radiation. The chronic exposure to these physical conditions leads to increase in the incidence of some occupational diseases. In a study, it was indicated that the most frequent reasons of death in coal miners were coal miner pneumoconiosis or related complications, tuberculosis, lung cancer and cardiovascular diseases ${ }^{5}$. In this study, carotid Doppler ultrasound, blood sample test and respiratory function test results were obtained from the files of the cases and these results were recorded. The effect (if any) of chronic exposure to coal mine dust on atherosclerotic process has been investigated in this study.

\section{MATERIALS and METHODS}

\section{Study Groups}

The study was a single centered and retrospective trial. The study consisted of total 100 patients, who applied to our hospital, and examined between April 2016 and December 2017 because of chest pain and/ or dyspnea. Initially, participants were divided into two groups as miners and healthy controls. Because some parameters were affected by age, the groups were reclassified in age groups. The ages of active coal miners and healthy, young controls ranged between 18, and 45 years. The ages of healthy elderly control group and veteran coal miners ranged between 46-75 years, so there were 4 groups in the study as follows: Group 1 (coal miners; $n=25$ ), and Group 2 (veteran coal miners; $n=25$ ) Group 3 ( $n=25$ young controls who have never worked in coal mines and never been exposed to coal dust), Group 4 ( $n=25$ : elderly controls have never worked in coal mines and never been exposed to coal dust). The patients with the following exclusion criteria were not included in the study: family history, acute-chronic renal-liverheart failure, diabetes mellitus, essential hypertension, rheumatological and endocrinological diseases, hyperlipidemia, coronary artery disease, heart valvular disease, history of cerebrovascular event and carotid arteries with plaques. The study protocol was approved by local ethics committee.

\section{Assessment of blood sample tests and arterial pres- sure}

The results of the following biochemical tests were retrieved from the files of the cases including fasting blood glucose, total cholesterol, low density lipoprotein cholesterol (LDL-C), high density lipoprotein cholesterol (HDL-C), triglycerides worked with colorimetric method (Cobas 8000 , Roche, Germany), hemogram parameters (BS-200, Mindray, Shenzhen, China) were recorded.

The mean cell volume (MCV) was calculated by the hematocrit $\times 10$ / erythrocyte count formula. In a 
healthy individual, normal values of MCV should be 78-93 $\mu 3$. The mean cell hemoglobin concentrationwas calculated by hemoglobin $(\mathrm{g} / \mathrm{dL}) \times 100 /$ hematocrit (\%) formula and normal range was considered as $27-34 \mathrm{~g} / \mathrm{dL}$. This parameters were retrieved from the files and recorded.

The arterial pressures of all participants, which were measured after 5 minutes rest at the outpatient clinic, were retrieved from the files and recorded.

\section{Echocardiographic evaluation}

The the information about diameters of the left and right heart chambers, valvular pathologies, ejection fractions $(\% \mathrm{EF})$, systolic pulmonary artery pressure (sPAB), pulmonary artery diameter, E/A ratio, tricuspid annular plan systolic excursion (TAPSE) which were measured from apical and parasternal axis by using $2,5 \mathrm{MHz}$ transducer of Vivid 5 echocardiography (GE Medical Systems, Hortan, Norway) were retrieved from the files and recorded.

\section{The evaluation of carotid arteries}

To determine the carotid intima-media thickness (CIMT), 3 segments of the carotid artery were imaged bilaterally by using an $11 \mathrm{MHz}$ transducer of an ultrasound machine (Aplio 500, Toshiba, Europe B.V.) in our centre. The CIMT was defined as the mean of the far wall CIMT measurements of the common carotid, carotid bifurcation, and internal carotid bilaterally. The carotid Doppler ultrasound reports were derived from the files and recorded.

\section{Respiratory function test results}

Reports of respiratory function tests (spirometry, MIR Spirolab III, Roma, Italy) performed according to the American Thoracic Society criteria (ATS) 6 were extracted from the files of participants. Reports of the respiratory function tests included data about forced expiratory volume in 1st second (FEV1), forced vital capacity (FVC), FEV1/FVC ratio, peak expiratory flow (PEF), the forced expiratory flow between $25 \%$ and $75 \%$ of vital capacity (FEF 25-75), body mass index (BMI), smoking status (former/current/never, pack/years).

\section{Statistical analysis}

In this study, Statistical Package for Social Sciences (SPSS) 20.0 for Windows, (Armonk New York USA), program was used for statistical analysis. The descriptive statistical methods (mean, standard deviation) were used to evaluate the data. Skewness-Kurtosis test showed whether variables had normal or non-normal distribution. Non-normally distributed variables, such as smoking status (pack-year), neutrophil/lymphocyte ratio (N/L), were assessed with Kruskal-Wallis test, while normally distributed variables were assessed with one-way ANOVA test. According to Kruskal-Wallis test, variables accounting for significant differences were compared with Mann Whitney $U$ test. The categorical variables were analyzed with Pearson chi square test. Linear regression analysis was used to explore the association of CIMT and FEV1, smoking (b/y), working time. Test results with $p<0.05$ was considered statistically significant.

Sample size calculation was based on the mean TAPSE. Mean TAPSE was reported as $1.54 \pm 0.17$ and $0.73 \pm 0.25$ in a previous study. Calculated with GPower 3.1 (http://www.gpower.hhu.de/), mean TAPSE gives a power of $80 \%$ with alpha $=0.05$ when comparing the two means by using Student t test with a total sample size of 38 participants. When one-way variance analysis in power analysis was made, similar results were obtained.

\section{RESULTS}

In our study there were 100 participants. The study consisted of 25 coal miners, 25 healthy young and 25 healthy elderly participants and 25 veteran coal miners. The mean number of work years of active coal miners were $11.03 \pm 5.92$ years, whereas the mean number of work years of veteran coal miners were $19.62 \pm 3.87$ years. The average years of retirement of coal miners were $10.68 \pm 7.55$ years. There was not any significant difference between the groups regarding systolic and diastolic blood pressures, 
Table 1. General characteristics of cases.

\begin{tabular}{|c|c|c|c|c|c|}
\hline & $\begin{array}{l}\text { Coal miners } \\
(n=25) \\
\text { (Group 1) }\end{array}$ & $\begin{array}{l}\text { Coal miner retirements } \\
(n=25) \\
\text { (Group 2) }\end{array}$ & $\begin{array}{l}\text { Young controls } \\
(n=25) \\
\text { (Group 3) }\end{array}$ & $\begin{array}{l}\text { Elderly controls } \\
(n=25) \\
\text { (Group 4) }\end{array}$ & $\mathbf{p}$ \\
\hline Age (years) & $39.76 \pm 5.33$ & $60.3 \pm 7.16$ & $36.36 \pm 3.24$ & $57.2 \pm 8.62$ & 0.000 \\
\hline Pulse (min) & $85.84 \pm 13.74$ & $79.8 \pm 14.81$ & $80.72 \pm 78.75$ & $80.20 \pm 16.92$ & 0.531 \\
\hline Diastolic blood pressure (mmHg) & $79.5 \pm 11.89$ & $76.5 \pm 11.15$ & $75.9 \pm 8.83$ & $79.03 \pm 9.66$ & 0.566 \\
\hline Systolic blood pressure (mmHg) & $130.5 \pm 11.89$ & $129.06 \pm 15.18$ & $124.72 \pm 9.09$ & $131.10 \pm 14.5$ & 0.341 \\
\hline Working time (years) & $11.03 \pm 5.92$ & $19.62 \pm 3.87$ & - & - & - \\
\hline Smoking status & $12(\% 48)$ & $10(\% 40)$ & $10(\% 40)$ & $12(48)$ & $0.715^{* *}$ \\
\hline Smoking (b/y) & $11.38 \pm 10.07$ & $18.2 \pm 17.85$ & $15.26 \pm 7.16$ & $27.24 \pm 17.1$ & $0.68 *$ \\
\hline BMI & $27.33 \pm 4.46$ & $29.63 \pm 4.47$ & $25.96 \pm 3.9$ & $27.41 \pm 3.30$ & 0.668 \\
\hline
\end{tabular}

$b / y=$ box/year; $B M I=$ body mass index.

p:One way ANOVA; *Kruskal-Wallis test; **Pearson chi square test

Table 2. Results of respiratory function test.

\begin{tabular}{llllll}
\hline & Group 1 & Group 2 & Group 3 & Group 4 & P \\
\hline FVC (L) & $4.12 \pm 0.67$ & $2.95 \pm 1.03$ & $4.31 \pm 0.74$ & $3.31 \pm 0.79$ & 0.000 \\
FEV1(L) & $3.49 \pm 0.5$ & $2.28 \pm 0.97$ & $3.59 \pm 0.59$ & $2.80 \pm 0.61$ & 0.000 \\
FEV1/FVC & $85.40 \pm 6.18$ & $76.15 \pm 14.98$ & $84.02 \pm 9.8$ & $85.14 \pm 8.2$ & 0.014 \\
PEF (L/s) & $7.47 \pm 1.7$ & $5.74 \pm 2.28$ & $6.14 \pm 2.08$ & $5.89 \pm 1.89$ & 0.000 \\
FEF25-75 (L/s) & $3.93 \pm 1.01$ & $3 \pm 1.33$ & $3.8 \pm 1.19$ & $3.17 \pm 0.87$ \\
\hline
\end{tabular}

FEF25-75= the forced expiratory flow between $25 \%$ and $75 \%$ of vital capacity; FEV1= forced expiratory volume in 1 st second; FVC= forced vital capacity; $P E F=$ peak expiratory flow.

p: One way ANOVA test.

heart rate, BMI ( $p$ values; 0.341; 0.566; 0.531; and 0.668 , respectively), but there was a significant difference with regard to age $(p<0.000)$. There was no significant difference between Groups 1 and 3 and between Groups 2 and 4 in post-hoc analysis of data concerning ages of the participants ( $p$ values 0.279 ; and 0.389 , respectively). The groups were compared in terms of smoking status (pack-years) and there was not any significant intergroup difference ( $p$ values 0.715 , and 0.68 , respectively). In Table 1 , the general characteristics of the participants were summarized. When groups were compared in terms of laboratory tests, there was not any meaningful intergroup difference in terms of fasting glucose, total cholesterol, LDL-C, HDL-C and triglyceride levels ( $p$ values; 0.065; 0.293 ; $0.176 ; 0.287$; and 0.228 respectively). When groups were compared in terms of hemogram parameters, there was a meaningful intergroup difference as for mean cell hemoglobin concentration (MCHC) and mean cell volume (MCV) $\mathrm{p}<0.05$; Table 3 ). The median $\mathrm{MCHC}$ values were $34.81 \mathrm{~g} / \mathrm{dL}$ in Group 3, in 32.91 $\mathrm{g} / \mathrm{d}$ in Group 1, and $32.81 \mathrm{~g} / \mathrm{dL}$ in Group 2. The median MCV values were $89.47 \mathrm{fL}$ in Group 2, $85.69 \mathrm{fL}$ in Group 3, and $85.52 \mathrm{fL}$ in Group 4. The MCV value was the highest in Group 2. There was not any difference among groups in terms of hemoglobin, hematocrit, neutrophil/lymphocyte ratio (N/L), platelet count, mean platelet volume (MPV). The results are summarized in Table 3. There was a difference among groups in terms of CIMT, which was measured using Doppler ultrasonography ( $p<0.000$; Table 4 , Graphic 1 ). In posthoc analysis, regarding CIMT values there was not any difference $(p=0.994)$ between Groups 1 and 3; however a statistically significant existed between Groups 2 and 4 there was difference $(p<0.05)$. When spirometry results were analyzed; there were significant intergroup differences as for FVC, FEV1, FEV1/FVC, PEF, and FEF25-75 values(respectively $p=<0.0001 ;<0.0001$; 
Table 3. The biochemical laboratory data of cases.

\begin{tabular}{|c|c|c|c|c|c|}
\hline & Group 1 & Group 2 & Group 3 & Group 4 & $\mathbf{P}$ \\
\hline Total cholestrol (mg/dL) & $195.07 \pm 34.52$ & $193.62 \pm 21.86$ & $181.18 \pm 34.69$ & $199.93 \pm 40.42$ & 0.293 \\
\hline $\mathrm{LDL}-\mathrm{C}(\mathrm{mg} / \mathrm{dL})$ & $121.42 \pm 30.44$ & $117.18 \pm 23.37$ & $110.27 \pm 30.87$ & $129.13 \pm 33.14$ & 0.176 \\
\hline $\mathrm{HDL}-\mathrm{C}(\mathrm{mg} / \mathrm{dL})$ & $41.42 \pm 9.86$ & $47 \pm 12.14$ & $44.72 \pm 7.21$ & $44.58 \pm 8.57$ & 0.287 \\
\hline Triglycerides (mg/dL) & $170.30 \pm 118.34$ & $139.5 \pm 80.26$ & $131.09 \pm 42.26$ & $130.86 \pm 45.92$ & 0.228 \\
\hline Fasting blood glucose (mg/dL) & $99.65 \pm 8.14$ & $98.62 \pm 10.49$ & $94.72 \pm 7.48$ & $101.13 \pm 8.39$ & 0.065 \\
\hline Hemoglobin $(\mathrm{g} / \mathrm{dL})$ & $14.7 \pm 1.32$ & $14.84 \pm 1.23$ & $14.43 \pm 1.17$ & $14,57 \pm 1.7$ & 0.797 \\
\hline Hematocrit (\%) & $44.37 \pm 3.71$ & $44.92 \pm 3.29$ & $42.09 \pm 3.23$ & $42.88 \pm 4.69$ & 0.077 \\
\hline Platelet $\left(10^{9} / \mathrm{L}\right)$ & $246.92 \pm 53.07$ & $225.37 \pm 60.1$ & $216.54 \pm 24.3$ & $222.86 \pm 60.48$ & 0.191 \\
\hline $\mathrm{MCH}(\mathrm{pg})$ & $29.43 \pm 2.98$ & $29.5 \pm 2.84$ & $29.42 \pm 1.93$ & $34.23 \pm 1.6$ & 0.187 \\
\hline $\mathrm{MCHC}(\mathrm{g} / \mathrm{dL})$ & $32.91 \pm 1.6$ & $32.81 \pm 1.55$ & $34.33 \pm 1.29$ & $33.7 \pm 1.97$ & 0.010 \\
\hline MPV (fL) & $9.68 \pm 0.93$ & $9.96 \pm 1.52$ & $9.45 \pm 1.03$ & $9.19 \pm 1.47$ & 0.191 \\
\hline MCV (fL) & $87.1 \pm 5.42$ & $89.47 \pm 7.25$ & $85.69 \pm 3.04$ & $85.52 \pm 4.71$ & 0.03 \\
\hline $\mathrm{N} / \mathrm{L}$ & $2.71 \pm 2.98$ & $2.29 \pm 1.9$ & $2.37 \pm 0.84$ & $1.99 \pm 0.58$ & 0.384 \\
\hline
\end{tabular}

$H D L-C=$ high density lipoprotein cholesterol; $L D L-C=$ low density lipoprotein cholesterol; $M C H=$ mean cell hemoglobin; $M C H C=$ mean cell hemoglobin concentration, $M C V=$ mean cell volume; $M P V=$ mean platelet volume; $N / L=$ neutrophil/lymphocyte ratio.

Table 4. The echocardiographic and carotid Doppler ultrasonographic data of cases.

\begin{tabular}{|c|c|c|c|c|c|}
\hline & Group 1 & Group 2 & Group 3 & Group 4 & $\mathbf{P}$ \\
\hline $\mathrm{EF}(\%)$ & $63.07 \pm 3.18$ & $59.68 \pm 4.26$ & $63.63 \pm 2.27$ & $61.55 \pm 4.45$ & 0.059 \\
\hline $\mathrm{sPAP}(\mathrm{mmHg})$ & $20.5 \pm 4.72$ & $24.26 \pm 9.6$ & $20.18 \pm 4.93$ & $23.52 \pm 5.45$ & 0.083 \\
\hline Pulmonary artery diameter $(\mathrm{cm})$ & $2.16 \pm 0.21$ & $2.23 \pm 0.33$ & $2.2 \pm 0.2$ & $2.22 \pm 0.19$ & 0.727 \\
\hline TAPSE $(\mathrm{cm})$ & $2.16 \pm 0.33$ & $2.1 \pm 0.29$ & $2.27 \pm 0.24$ & $2.16 \pm 0.19$ & 0.057 \\
\hline $\mathrm{E} / \mathrm{A}$ & $1.02 \pm 0.18$ & $0.86 \pm 0.17$ & $0.90 \pm 0.17$ & $0.91 \pm 0.24$ & 0.065 \\
\hline Intima media thickness (cm) & $0.66 \pm 0.16$ & $0.99 \pm 0.09$ & $0.65 \pm 0.16$ & $0.81 \pm 0.13$ & 0.000 \\
\hline
\end{tabular}

$H D L-C=$ high density lipoprotein cholesterol; $L D L-C=$ low density lipoprotein cholesterol; $M C H=$ mean cell hemoglobin; $M C H C=$ mean cell hemoglobin concentration, $M C V=$ mean cell volume; $M P V=$ mean platelet volume; $N / L=$ neutrophil/lymphocyte ratio.

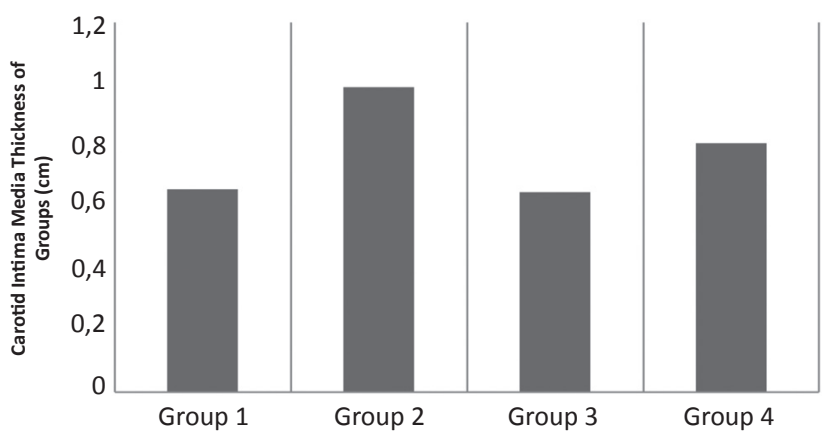

Graphic 1. Mean values of intima media thickness in the groups.

$<0.05 ;<0.0001 ;<0.0001$, respectively).The results are summarized in Table 2 and Graphic 2. When echocardiographic parameters were assessed, there was not any intergroup significant difference concerning values for EF, SPAB, TAPSE, left ventricle systolic and diastolic diameters. The results are summarized in Table 4.

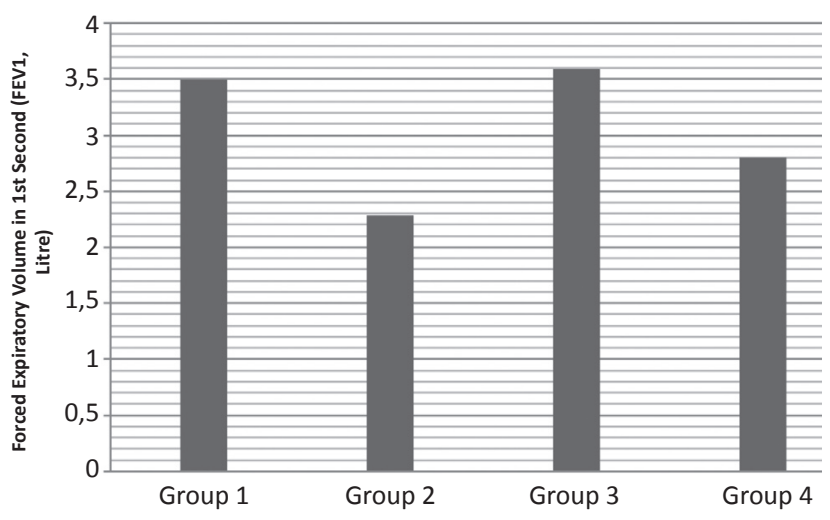

Graphic 2. Mean values of FEV1 in the groups.

A linear regression analysis was performed in the stage which the carotid intima-media was the dependent variable. The FEV1, smoking (b/y), working time were determined as independent variables. In this analysis, there was a negative correlation between FEV1 and CIMT while a positive correlation 
Table 5. Linear regression analysis.

\begin{tabular}{|c|c|c|c|c|c|c|}
\hline & \multirow[b]{2}{*}{ Model } & \multicolumn{2}{|c|}{ Unstandardized Coefficients } & \multirow[t]{2}{*}{ Standardized Coefficients } & \multirow[t]{2}{*}{$\mathbf{T}$} & \multirow[t]{2}{*}{ Sig. } \\
\hline & & B & Std. Error & & & \\
\hline \multirow{4}{*}{1} & (Constant) & 1.015 & .072 & & 14.027 & .000 \\
\hline & Smoking (Box/year) & .001 & .001 & .174 & 1.958 & .053 \\
\hline & Working years & .005 & .002 & .211 & 2.311 & .023 \\
\hline & FEV1 & -.98 & .021 & -.424 & -4.638 & .000 \\
\hline
\end{tabular}

a. Dependent Variable: Intima media thickness.

was determined between CIMT and working years. There was not any meaningful relationship between smoking and CIMT. The data are shown in Table 5.

\section{DISCUSSION}

According to World Health Organization, in 2015 56,4 million death occurred ${ }^{7}$. It was seen that 15 million of these deaths were originated from ischemic heart disease and cerebrovascular events ${ }^{7}$. Cardiovascular diseases are among the most frequent cause of death all over the world and they are also common causes of death among coal miners 8,9. In the study done by Lai et al., coal miners and control group were compared in terms of hypertension and electrocardiographic (ECG) abnormalities. In the coal miners group, hypertension, and ECG abnormalities were found to be more frequent. In the same study, cardiovascular abnormalities were found to be more frequent in underground workers ${ }^{10}$. The pulse wave velocity is a traditional independent marker for cardiovascular mortality. In a study comparing coal miner pneumoconiosis and control group in terms of brachial artery pulse wave velocity, the pulse wave velocity was found to be higher in coal miners group $^{11}$. The atherosclerosis is the most common cause of cardiovascular and cerebrovascular events. Atherosclerotic carotid arteries can be most easily visualized using imaging modalities. For this reason, increased CIMT can be use as an early marker of atherosclerotic process ${ }^{12-15}$. In this study, the intima media thickness was higher in Group 2, when compared with Group 4. However there was not any difference between young controls and active coal miners in terms of CIMT. According to these results, it can be thought that chronic and long time exposure to coal mine dust can cause increase in CIMT.

There was not any difference among the groups in terms of smoking, BMI and lipid profile, which are the risk factors for atherosclerosis. According to these findings, it may be concluded that coal mine dust contributes to atherosclerotic process.

In this study, it was determined that the MCV and $\mathrm{MCHC}$ values of the groups were within the normal range. However, when groups were compared with each other, it was determined that there were meaningful differences between groups. MCV was the highest, but MCHC was the lowest in Group 2. It can be thought that these results may be related to respiratory disorders. Since there are studies showing that people with chronic obstructive pulmonary disease often have macrocytosis ${ }^{16,17}$, it was thought that macrocytosis is secondary to hypoxemia. In this study, when spirometry results were evaluated, it was observed that FEV1, FVC, FEV1/FVC, PEF, FEF2575 values were at their lowest in Group 2. Therefore, it was concluded that blood oxygenation was low due to respiratory disorders in group 2.

The coal dust passes through inhalation to the extreme end of the lungs, terminal bronchovascular bundle and accumulates in alveolar macrophages. Then, chronic inflammatory process begins. Chronic bronchitis, emphysema, coal miner pneumoconiosis can occur due to chronic exposure to coal dust in workers ${ }^{18}$. The first changing parameter in these 
individuals is FEV1. In the study done by Wang et al, it was observed that there was a rapid decrease in FEV1 parameter in the first work years of coal miners $^{19}$.

\section{LIMITATIONS}

The most important limitation was the small number of participants. Another important limitation was that the in-pit exposure was not supported by the data because of study design. This study had a retrospective design and the data were obtained from the patients' files. The carotid Doppler ultrasonography and echocardiography were performed by different operators which was another limitation of our study.

\section{CONCLUSIONS}

In conclusion, in this study it was found that the carotid intima- media thickness which is used for early diagnosis of atherosclerosis, increases after chronic exposure to coal mine dust. For this reason, professional questioning may be useful when risk factors for atherosclerosis are to be determined.

\section{CONFLICT OF INTEREST}

In this study, there was no conflict interest.

\section{REFERENCES}

1. Tasneem Z. N., Ming-Sum L. Carotid intima-media thickness and plaque in cardiovascular risk assessment. 2014;7:102538.

2. Mukherjee D. Carotid artery intima-media thickness: indicator of atherosclerotic burden and response to risk factor modification. Am Heart J 2002;144:753-9. https://doi.org/10.1067/mhj.2002.124865

3. Lewis Hk, Alice MA, Bruce MP, et al. Disease and risk of coronary heart disease in the cardiovascular health study. Arch Intern Med. 2006;166:71-8. https://doi.org/10.1001/archinte.166.1.71

4. O'Leary DH, Polak JF. Intima-media thickness: a tool for atherosclerosis imaging and event prediction. Am J Cardiol 2002;90:18-21.

https://doi.org/10.1016/S0002-9149(02)02957-0
5. Han L, Gao Q, Yang J, et al. Survival Analysis of Coal Workers' Pneumoconiosis (CWP) Patients in a State-Owned Mine in the East of China from 1963 to 2014. Int J Environ Res Public Health. 2017;14:489.

https://doi.org/10.3390/ijerph14050489

6. Miller MR. Standardisation of spirometry. Eur Respir J. 2005;26:319-38.

https://doi.org/10.1183/09031936.05.00034805

7. http://www.who.int/gho/mortality_burden_disease/ causes_death/top_10/en/

8. Chen $\mathrm{W}$, Liu $\mathrm{Y}$, Wang $\mathrm{H}$, et al. Long-term exposure to silica dust and risk of total and cause-specific mortality in chinese Workers: A cohort study. PLoS Med. 2012;9:e1001206. https://doi.org/10.1371/journal.pmed.1001206

9. Landen DD, Wassell JT, McWilliams L, et al. Coal dust exposure and mortality from ischemic heart disease among a cohort of U.S. coalminers. Am J Ind Med. 2011;54:727-33. https://doi.org/10.1002/ajim.20986

10. Lai Z,Wang X, Tan H, et al. Effect of underground work on cardiovascular systemin coal miners. Zhong Nan Da Xue Xue Bao YiXue Ban. 2015;40:1103-8.

11. Zheng $Y$, Liang $L$, Qin T, et al. Cross-section analysis of coal workers' pneumoconiosis and higher brachial-ankle pulse wave velocity within Kailuan study. BMC Public Health 2017;17:148. https://doi.org/10.1186/s12889-017-4048-7

12. Bartels S, Franco AR, Rundek T. Carotid intima-media thickness (Cımt) and plaque from risk assessment and clinical use to genetic discoveries. Perspectives in Medicine 2012;1:13945 . https://doi.org/10.1016/j.permed.2012.01.006

13. Mathiesen EB, Johnsen SH. Ultrasonographic measurements of subclinical carotid atherosclerosis in prediction of ischemic stroke. Acta Neurol Scand. 2009;120:68-72. https://doi.org/10.1111/j.1600-0404.2009.01210.x

14. Spence JD. Measurement of intima-media thickness vs. carotid plaque: uses in patient care, genetic research and evaluation of new therapies. Int J Stroke 2006;1:216-21. https://doi.org/10.1111/j.1747-4949.2006.00068.x

15. Altın C, Sade LE, Gezmiş E, Yılmaz M, Özen N, Müderrisoğlu H. Assessment of epicardial adipose tissue and carotid/femoral intima media thickness in insulin resistance. J Cardiol. 2017 Jun; 69:843-50. https://doi.org/10.1016/j.jjcc.2016.08.006

16. Pachon EG, Navas IP. Red cell macrocytosis in COPD patients without respiratory insufficiency: A brief report. Respiratory Medicine. 2007;101:349-52. https://doi.org/10.1016/j.rmed.2006.05.003

17. Tsantes AE, Papadhimitriou SI, Tassiopoulos ST, et al. Red cell macrocytosis in hypoxemic patients with chronic obstructive pulmonary disease. Respir Med. 2004;98:1117-23. https://doi.org/10.1016/j.rmed.2004.04.002

18. Perret J, Plush B, Lachapelle $P$, et al. Coal mine dust lung disease in modern era. Respirology 2017;22:662-70. https://doi.org/10.1111/resp.13034

19. Wang $M$, Wu Z, Du Q, et al. Prospective cohort study among new Chinese coal miners:the early pattern of lung function change. Occup Environ Med. 2005;62:800-5. https://doi.org/10.1136/oem.2005.020271 